\title{
Conceptualizing Supplier Work Passion in light of the Zigarmi's Framework
}

\author{
Muhammad Nawaz',2,* $\mid$ Sara Javed $^{2}$ | S. Mutahir Hussain Shah ${ }^{3}$ | \\ Maria Mustafa ${ }^{1} \mid$ Unsa $^{1} \mid$ Alina Namatullah ${ }^{1}$ \\ ${ }^{1}$ National College of Business Administration e Economics, Lahore, Pakistan \\ ${ }^{2}$ Management Research Centre, GreySys Foundation, Lahore, Pakistan \\ ${ }^{3}$ Institute of Business $\Theta$ Management, University of Engineering and Technology, Lahore, Pakistan \\ *Corresponding author: m_nawaz_progressive@yahoo.com
}

Received 7 April 2021; Revised 13 May, 13 June, 21 July 2021; Accepted 22 July 2021

\begin{abstract}
Similar to other systems, the supply chains are also evolving, and old problems are seeking a new outlook. Work passion is an important concept in human resource management literature, but it rarely sought attention in supply chain management literature in the context of suppliers. By building upon some works by Drea Zigarmi on the employee work passion, the current study makes a pioneering attempt in defining supplier work passion and then conceptualizing it through an eight-dimensional construct. Therefore, a novel framework has been constructed. It is argued that a supplier can be an organization, but it behaves like a passionate individual in its dealing with the buyers. The study is of theoretical and practical significance and is likely to create a new debate in supply chain management on the significance of supplier work passion.
\end{abstract}

Keywords: Supplier work passion; Business relationship management; Organizational behavior; Supply chain management

\section{Introduction}

Organizations attempt to recruit the best-fit employees along with enhancing the performance of existing employees (Nawaz et al., 2020). Inline, it would be plausible if organizations recruit passionate employees, which might be imperative to bring the organizational performance upward. Not only organizations but supply chain integration also requires passionate people (McCarter, Fawcett, \& Magnan, 2005). Supply chain management (SCM) is a transformative field growing while absorbing ideas from different fields (Mahmoudi et al., 2021; Wieland, 2021). Given that, the classic work of Dauch and Troyanovich (1993) discussed the significance of building teams, Just-In-Time material management, flexible production system, product quality, and work effectively with unions and suppliers. In social psychology, passion is a motivational construct that is domain-specific (Chen et al., 2009). Johri et al. (2016) found that the concept of passion has been studied in three different contexts 1) in the context of work, 2) in the context of activities, and 3) in the context of entrepreneurship. Although work passion is relevant for people, it is not irrelevant for organizations.

Perttula (2004) has defined passion for work in the context of work as a psychological state described by a sense of imperative connection towards an individual's work, the experience of strong positive emotions, and an internal drive to work. According to this conceptualization, work passion is a state 
consisting of both cognitive and emotional components (meaningful connection and internal drive, joy, and subjective vitality, respectively). Here, a meaningful connection refers to intertwined an individual identity with his/her work. The emotional aspects here deal with a feeling of love towards work, happiness and enjoyment, joy, and other dimensions of work passion. While talking about passion, if an individual does it through the mental process, then that individual becomes passionate about work (Zigarmi et al., 2009). Further, Zigarmi defined work passion as an individual's state of emotionally positivity, persistent state of well-being, affective and cognitive appraisals of various jobs.

Vallerand et al. (2003) proposed the most prominent definition of passion in the context of activities as passion is a strong inclination in which individuals invest energy and time, consider it important, and like it as is self-defining activity. Further, they also proposed "obsessive passion (OP) and harmonious passion (HP)" as the two types of passion in the context of activities. These types of passion differ on the basis of personal identity, e.g., self-determination theory (Deci \& Ryan, 2000). Obsessive passion typically involves creating an internal pressure, a controlled internalization of activities in individuals' identity to engage in the activities that please them (Vallerand et al., 2003). Whereas, to engage individuals in the activity they like, the autonomous internalization is called harmonious passion (Vallerand et al., 2003).

To define work passion, the emotional component of passion in the context of entrepreneurship has been the focus of academicians, for instance, passion is elaborated as selfish love of work (Shane, Locke \& Collins, 2003; Baum \& Locke, 2004). Further, Smilor (1997) defined passion as zeal, joy, and enthusiasm that emanate from the vital pursuit of a worthy, challenging, and uplifting purpose. Later making passion a single construct, Cardon et al. (2009) provided the concept of entrepreneurial passion by integrating motivational and emotional component. Consequently, entrepreneurial passion is feeling that is defined as "consciously accessible intense positive feelings experienced by engagement in entrepreneurial activities associated with roles that are meaningful and salient to the self-identity of the entrepreneur" (Cardon et al., 2009).

In the disciplines dominated by technologies, techniques, and technical people, it is no wonder "soft" issues are usually overlooked as "hard" issues get most of the attention (Javed et al., 2018). Supply chain management is no exception. Literature is abundant on supplier selection problems and other hard issues related to SCM; however, the soft issues received less attention from scholars and practitioners alike. For instance, Murphy and Smith (2009) recognized the insignificant amount of research dedicated to understanding the suppliers' perspectives. Inline, Jia et al. (2014) also recognized the importance of developing theory in this context. Passion has been studied extensively in different industries, from the entertainment industry (Klein, 2007) to the healthcare sector (Luo et al., 2014), to the education sector (Gilal et al., 2019), and the general work environment (Murnieks \& Cardon, 2019). However, to the best of our knowledge, the suppliers' work passion has rarely been studied, if ever. The current study attempts to fill this gap by making a pioneering attempt in conceptualizing and defining the supplier work passion.

\section{What is work passion, and what isn't?}

Based on preceding notions (e.g., Zigarmi et al., 2010), work passion is defined as a person's persistent and emotional state of desire based on cognitive and affective work appraisals that lead to consistent work behaviors and intentions. These consistent behaviors and intentions contain everything from being determined to organizational citizenship behaviors. From the literature (Zigarmi et al., 2009), it is likely that work passion overlaps and also could be interchangeable with different constructs. Nonetheless, we argued about the work passion as it owns distinctive abilities that support its distinctiveness. As a result, we describe the association of work passion with empowerment, intrinsic motivation, job engagement, and other possible consequences. Given that, Conger and Kanungo (1988) defined empowerment as a form of and to improve self-efficacy. Thus, empowerment is deliberated as a cognitive state (related to work passion) that focused on self-perceptions of control and ability.

While talking about emotionality and work passion, emotionality having the elements of liking and well-being, not included in empowerment but has been involved in many thoughts of work passion (Zigarmi et al., 2009). On the other hand, talking about work engagement, Harter et al. (2002) made enthusiasm a part of work engagement. Besides, work passion provides encouragement in the form of incentives, which is more proactive and extensive. Extending this argument, we observed that 
engagement is too closely associated with the literature of organizational commitment, job involvement, and burnout.

More importantly, from the above discussion, it is easy to say that engagement does not cover the degree of work passion and impact of work passion on individuals. Employees are emotionally focused on the activities they like (Nawaz et al., 2018) and intend to produce favorable responses. However, rather than simply affect, the construct of work passion is more wide-ranging. Affect is not necessarily be associated with organizational activities for which employees are passionate. Thus, affect, compared to passion, has more global feelings of negative or positive emotions. Feelings related to work passion are directed to definite activities such as constructing sales reports and networking. Further, employees may also direct their passion towards certain individuals. Finally, intrinsic motivation refers to pleasure and fulfillment derived from short-term inter-personal task interactions (Ryan \& Deci, 2000). Taking the concept of intrinsic motivation, affect, and engagement, the work passion is habitually a selfenhancing state, and hence flattering a stable feature of individuals' identity (Vallerand et al., 2003).

Work passion is highly interrelated to work engagement. In this regard, a number of parameters have been discussed in the literature in which (1) a clear framework is still missing explaining the antecedents and consequences, (2) few common conceptual components have been used by both academicians and practitioners, and (3) convincing evidence were available showing that engagement is a multidimensional construct. Three research implications based on the social cognitive theory of appraisal (SCTA) have been drowned (Zigarmi et al., 2011), (1) to better understand the work passion, the affective aspect of appraisal should be assessed, (2) valuation cognition and intention cognition should be differentiated, and (3) intention and behavior should be differentiated. Besides these parameters, work passion has mainly been neglected to be discussed with the new context of specific employee' category. Furthermore, to the best of our knowledge, the literature also neglected the exploration of organizational work passion, as in certain situations, an "individual" can have characteristics of both an individual and an organization. For instance, a supplier can be an individual or organization. Can we say when a supplier is an individual, it can be passionate about work, but when it is an organization, it cannot be? The literature is silent on such questions.

\subsection{Dark side of work passion and its associated outcomes}

The bright side of work passion has been linked with positive moods and emotions, including potency and optimism (Zigarmi et al., 2010). However, the dark sides of work passion can be observed when work passion reaches an obsessive or excessively high level (Ho et al., 2011). For instance, uncontrolled rumination is associated with extreme passion and inflexibility (Ratelle et al., 2004; Vallerand et al., 2003). Moreover, passion at its extreme level is associated with aggressive behaviors, including the following aspects: the accumulation of job-related materials, eradicating barriers, and supporting the active detection of goals (Cardon et al., 2009). Thus, when there is high passion in employees, behaviors, and intentions may be considered threatening. Finally, obsessive passion levels may lead to persistence that hinders interpersonal relationships with peers and task completion (Vallerand et al., 2010).

In sum, employees who are just way too into work can easily be identified, they often are shunned by others, and their performance can vary passionately. Thereby, we argue that passion affects the behaviors at large so that how behaviors are internally scripted and externally presented. Research has acknowledged that self-regulation is essential while predicting the failure and success of passion-driven behavior (Lafrenière et al., 2011). Research opportunities associating passion with directories of selfcontrol are challenging yet abundant (Baumeister et al., 2005). In the supply chain context, the dark dimension of work passion is equally important. We can recall many cases (Lewis, 2021, Nix, 2019) where a potential supplier tried to improperly influence a deal or even sued the buyers for not seeking their services. Can we attribute the misconducts in the supplier-buyer relationships to the dark side of supplier work passion?

\section{The Proposed Framework of Supplier Work Passion}

Drea Zigarmi and colleagues pioneered one of the most refined and well-established frameworks of work passion (Zigarmi et al., 2009), referred to as the Zigarmi's Framework in the current study. By summarizing their point of view, we conclude that the three components such as affect, intentions, and 
Table 1. The nine-dimensional construct of the supplier work passion

\begin{tabular}{|l|l|}
\hline Dimension & \multicolumn{1}{c|}{ Perceived Meaning } \\
\hline Autonomy & $\begin{array}{l}\text { A supplier perceives a business environment where both parties have the tools, training, } \\
\text { support, and authority to make selling and buying decisions. }\end{array}$ \\
\hline Collaboration & $\begin{array}{l}\text { A supplier perceives the environment and culture of the business partnership that improves } \\
\text { its collaboration and cooperation with its buyers. }\end{array}$ \\
\hline Fairness & $\begin{array}{l}\text { A supplier perceives the business environment where revenue, resources, and opportunities } \\
\text { are fair and balanced and equitable, and both partners treat each other with respect and as per } \\
\text { the commitment. }\end{array}$ \\
\hline Growth & $\begin{array}{l}\text { A supplier perceives a business environment where it has an opportunity to learn, grow, and } \\
\text { develop capabilities that lead to profitability and business growth. }\end{array}$ \\
\hline Innovativeness & $\begin{array}{l}\text { A supplier perceives a business environment where its work passion could be highly } \\
\text { compatible with technological changes and its innovativeness seek out new sources of useful } \\
\text { information. }\end{array}$ \\
\hline Meaningful work & $\begin{array}{l}\text { A supplier perceives the buyers' larger purpose through products and services they buy, } \\
\text { considers its services to be worthwhile, and are proud of its contributions and actions that } \\
\text { help the buyers serve their customers. }\end{array}$ \\
\hline Recognition & $\begin{array}{l}\text { A supplier perceives a business environment where it is recognized and appreciated by the } \\
\text { buyers for its extraordinary contributions, where it receives future orders for these } \\
\text { contributions, and where it is contributing to a positive relationship with the buyers. }\end{array}$ \\
\hline $\begin{array}{l}\text { Connectedness with } \\
\text { the buyers }\end{array}$ & $\begin{array}{l}\text { A supplier perceives a business environment where it is trusted by the buyers and where they } \\
\text { make an effort to form long-term business relationships with it. }\end{array}$ \\
\hline $\begin{array}{l}\text { Connectedness with } \\
\text { the industry }\end{array}$ & $\begin{array}{l}\text { A supplier perceives a business environment where it is trusted by the industry (and market) } \\
\text { and is furnished with the support it required for long-term sustainability. }\end{array}$ \\
\hline
\end{tabular}

cognition, must be assimilated into any useful definition of passion, satisfaction, or commitment. By using the appraisal construct affect, intention, and cognition, we understand the operational definition of work passion as follows (Zigarmi et al., 2009: 310).

"Employee work passion is an individual's persistent, emotionally positive, meaning-based, and state of well-being stemming from reoccurring cognitive and affective appraisals of various job and organizational situations that results in consistent, constructive work intentions and behaviors."

As can be observed, work passion is a higher-order construct that can be explained and examined by incorporating several conceptual relationships. Since intentions and behaviors are meaning-based elements, so the element of persistence and values motivation exist which intentionally and conceptually are the basis for discretionary efforts, organizational citizenship behavior, and excellent performance over time.

An appraisal is an ongoing occurrence that is a latent aspect of the operational definition, the outcome from an ongoing appraisal process. It also implies that, depending upon the characteristics of the nature of work and organization, different variables may come into play in different time durations. Thus, the term situation is a significant point of discussion here that relies on an ongoing historical association, thus creating various meanings and experiences. The proposed context, i.e., the supplier work passion with innovation as one of its core constructs, is also highly important here as passionate suppliers may possess cognitive elements that encourage them for creative thinking and ultimately result in innovation.

The literature categorizes the employee work passion into eight elements (Zigarmi et al., 2011): 1) meaningful work, 2) collaboration, 3) fairness, 4) autonomy, 5) recognition, 6) growth, 7) connectedness with the leader, and 8) connectedness with colleagues. Based on the above discussion and considering its importance in supply chain management (Bai \& Sarkis, 2010), innovativeness can also be added to it. It is believed that if suppliers would pay attention to the elements of work passion, then high work passion in suppliers can probably be observed, and when they are passionate, then the thrust of innovation may be produced in the cognition of suppliers. In light of the work of Zigarmi et al. (2009), and considering the importance of innovation in the supplier-buyer relationship, the construct of supplier work passion has been developed and presented in Table 1, while the complete supplier work passion model has been shown in Figure 1. Meanwhile, by building upon the work of Zigarmi et al. (2009) and the nine-dimensional construct of supplier work passion discussed in Table 1, the current study pioneers the operational definition of supplier work passion, which is defined as: 


\begin{abstract}
A supplier work passion is a supplier's persistent, compatible with technological changes, ideologically positive, meaning-based state of well-being stemming from reoccurring cognitive and affective appraisals of various work situations that results in consistent, constructive work intentions and behaviors towards the buyer and the industry.
\end{abstract}

\title{
4. Discussion
}

Zigarmi's framework explained certain fundamentals about the occurrence of work passion. Appraisal concept clearer the picture of antecedents and development of work passion. From the research methodology point of view, a separate measure is needed to confirm, delineate, and explain various aspects if a construct is to be validated (Breckler, 1984). The three components (intention, cognition, and affect) are unobservable, hypothetical constructs, and thereby no single measure was assumed in terms of work passion. Similarly, this study suggests that by considering the importance of suppliers' work passion, there is a dire need to develop the measure of supplier work passion. By taking this measure, the modifiers, antecedents, and consequences of supplier work passion would be more fully understood.

In todays' world, technology is considered the engine of growth, and organizations need to keep change with rapid advancements in technology. For contemporary organizations, perhaps, the greatest challenge is the integration and acquisition of technology in their structure, strategy, and process. In this context, the compatibility of work passion could be high with these technological changes. Endless creative thinking and innovation need to espouse organizations in such a competitive environment to gain a competitive advantage.

It was observed that employees having a passionate state can easily adapt the challenging situations (Gubman, 2004). Similarly, the supplier work passion would be compatible with technological changes. Thereby, the buyers' need to buy from passionate suppliers is augmented. In addition, two outcomes might be succeeded by supplier work passion (a) creative thinking and innovation to seek out new sources of knowledge, and (b) tap out insight for building relationships (Hagel III et al., 2010). Thus, buyers and industry (market) need to recruit innovative and passionate suppliers to move forward with continuous improvements. To date, there has been only one study (i.e., Zigarmi et al., 2011) which, instead of personal characteristics, investigated the association of work environment characteristics with work passion. Thus, it has important implications for developing a construct for supplier work passion. Considering the significance of supplier work passion, the current study recommends developing a measure on supplier work passion to which basic accompaniment and support is provided in the current study. Inline, the supplier work passion can empirically be investigated with dispositional antecedents.

One may argue that passion is an individual characteristic or a behaviour exhibited by individuals, is it logical to extend it to an organizational entity like a supplier? Here, the study argues that the supplier may or may not be an organization. For example, in many cases, small businesses usually buy from suppliers who happen to be individuals. These individuals may or may not be acting on behalf of an organization. Generally, it is more likely that a supplier may be an organization. If an organization can

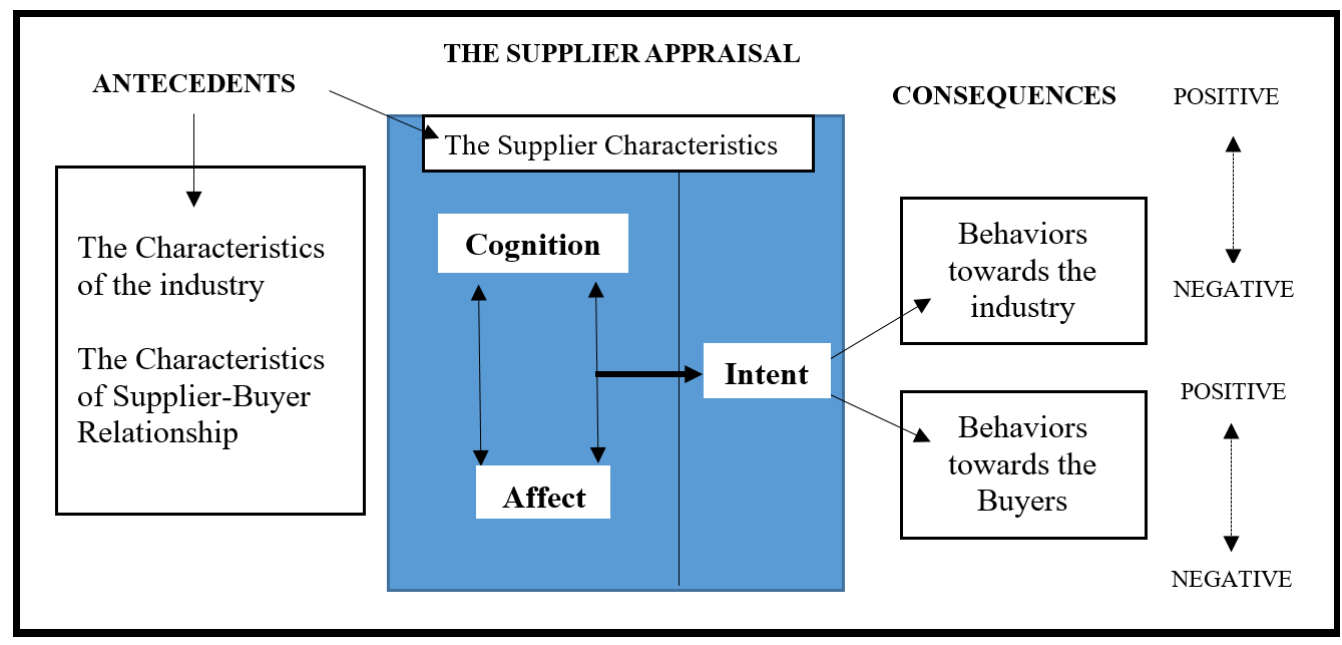

Figure 1. The supplier work passion model (adapted from Zigarmi et al., 2009: 310) 
have a 'vision,' 'mission,' and 'power,' what's wrong with having a 'passion'? Isn't an organization merely a group of individuals? It is true that passion is mainly associated with corporate founders, business leaders, entrepreneurs, employees, workers, and other individuals (Makino et al., 2020; Balon \& Rimé, 2013). Interestingly, some writers did indeed mention "passionate organization" (Lucas, 1999), a research organization's "passion" [for science] (Nature, 2020), a newspaper's "passion" [for criticism] (Stalin, 1954), and a country's "passion" [for education] (Regan, 2018). However, it should be noted that in the end, the passion of an organizational entity (e.g., a supplier firm's passion for the work for a buyer firm) is supposed to be the sum of the passion of the people who make the organization. The current study argues that an organization can also exhibit passion, but the form of this passion can be different from employee's passion and is a subject of future studies. Also, for those who recognize passion as "the first source of all our enquiries" (Martin, 2021), and know business and market enquiries are an integral part of any organization, it is not difficult to appreciate the proposed concept of supplier work passion irrespective of the fact we view supplier as an individual, group or an organization.

\section{Conclusion}

Work passion remains a popular topic in the literature concerning human resources and organizational behavior (Hagel III et al., 2010; Perttula, 2004; Carpentier, Mageau \& Vallerand, 2012). Johri et al. (2016) defined passion in the context of 'work', 'activities', and 'entrepreneurship'. The current study adds to it 'business relationship' as well, where business relationship implies the profitable relationship between the provider of a service or product and its buyer. The supplier-buyer relationship is a particular example of this relationship. Meanwhile, the study proposes a novel definition and construct of supplier work passion. Also, 'innovation' has been introduced in the construct of work passion. Thus, in the current study, a novel framework of supplier work passion has been proposed.

Since the framework is new and original, further research is needed to develop the scale of supplier work passion and test its antecedents and consequences empirically with various constructs. Also, how to quantify or estimate supplier work passion is another area of future research. While noting that the scientific literature is almost silent on the passion demonstrated by an organization, the current study has initiated a debate for future researchers, especially from the disciplines of organizational behavior and supply chain management. How does the scientific community responds to this initiative is yet to be seen.

\section{Acknowledgements}

The idea of supplier work passion emerged in a meeting between the first two authors and Dr. S. A. Javed, an associate professor of supply chain management. The authors thank him for the insightful discussion and comments.

\section{References}

Bai, C., \& Sarkis, J. (2010). Integrating sustainability into supplier selection with grey system and rough set methodologies. International Journal of Production Economics, 124(1), 252-264. https://doi.org/10.1016/j.ijpe.2009.11.023

Balon, S., \& Rimé, J. L. B. (2013). Passion and personality: Is passionate behaviour a function of personality? Passion et personnalité : le comportement passionné s'exprimerait-il en fonction de la personnalité?, European Review of Applied Psychology, 63(1), 59-65. https://doi.org/10.1016/j.erap.2012.06.001

Baum, J. R., \& Locke, E. A. (2004). The relationship of entrepreneurial traits, skill, and motivation to subsequent venture growth. Journal of Applied Psychology, 89(4), 587-598. https://doi.org/10.1037/0021-9010.89.4.587

Baumeister, R., DeWall, C., Ciarocco, N., \& Twenge, J. (2005). Social exclusion impairs self-regulation. Journal of Personality and Social Psychology, 88, 589-604. https://doi.org/10.1037/0022-3514.88.4.589

Breckler, S. J. (1984). Empirical validation of affect, behavior, and cognition as distinct components of attitude. Journal of Personality and Social Psychology, 47(6), 1191-1205.

Cardon, M.S., Wincent, J., Singh, J., \& Drnovsek, M. (2009). The nature and experience of entrepreneurial passion. Academy of Management Review, 34(3), 511-532.

Carpentier, J., Mageau, G. A., \& Vallerand, R. J. (2012). Ruminations and flow: Why do people with a more harmonious passion experience higher well-being?. Journal of Happiness Studies, 13(3), 501-518. https://doi.org/10.1007/s10902-011-9276-4 
Chen, X. P., Yao, X., \& Kotha, S. (2009). Entrepreneur passion and preparedness in business plan presentations: a persuasion analysis of venture capitalists' funding decisions. Academy of Management Journal, 52(1), 199-214.

Conger, J., \& Kanungo, R. (1988). The empowerment process: Integrating theory and practice. Academy of Management Review, 13, 471-482. https://doi.org/10.2307/258093

Dauch, R. E., \& Troyanovich, J. (1993). Passion for manufacturing. Society of Manufacturing Engineers. ISBN: 9780872634367

Deci, E. L., \& Ryan, R. M. (2000). The" what" and" why" of goal pursuits: Human needs and the self-determination of behavior. Psychological Inquiry, 11(4), 227-268. https://doi.org/10.1207/S15327965PLI1104_01

Gilal, F. G., Channa, N. A., Gilal, N. G., Gilal, R. G., \& Shah, S. M. M. (2019). Association between a teacher's work passion and a student's work passion: a moderated mediation model. Psychology Research and Behavior Management, 12, 889-900. https://doi.org/10.2147/PRBM.S212004

Gubman, E. (2004). From engagement to passion for work: The search for the missing person. Human Resource Planning, 27(3), 42-46.

Hagel III, J., Brown, S. J., Kulasooriya, D., \& Elbert, D. (2010). Measuring the forces of long-term change: The 2010 shift index. Deloitte Center for the Edge, 2. Retrieved from http://www.consejosalta.org.ar/wpcontent/uploads/Shift-Index2010.pdf

Harter, J. K., Schmidt, F. L., \& Hayes, T. L. (2002). Business-unit-level relationship between employee satisfaction, employee engagement, and business outcomes: A meta-analysis. Journal of Applied Psychology, 87, 268-279. https://doi.org/10.1037/0021-9010.87.2.268

Ho, V. T., Wong, S. S., \& Lee, C. H. (2011). A tale of passion: Linking job passion and cognitive engagement to employee work performance. Journal of Management Studies, 48(1), 26-47. https://doi.org/10.1111/j.14676486.2009.00878.x

Javed, S. A., Syed, A. M., \& Javed, S. (2018). Perceived Organizational Performance and Trust in project manager and top management in Project-based organizations: Comparative Analysis using Statistical and Grey Systems methods. Grey Systems: Theory and Application, 8(3), 230-245. https://doi.org/10.1108/GS-01-20180009

Jia, L., Xu, Y., \& Wu, M. (2014). Campus Job Suppliers' Preferred Personality Traits of Chinese Graduates: A Grounded Theory Investigation. Social Behavior and Personality, 42(5), 769-782. http://dx.doi.org/10.2224/sbp.2014.42.5.769

Johri, R., Misra, R. K., \& Bhattacharjee, S. (2016). Work Passion: Construction of Reliable and Valid Measurement Scale in the Indian Context. Global Business Review, 17(3_suppl), 147S-158S. https://doi.org/ $10.1177 / 0972150916631206$

Klein, A. (2007). Work/Love/Film: Exploring the Ambiguities of Definition in Godard's Passion. Quarterly Review of Film and Video, 24(1), 41-51. https://doi.org/10.1080/10509200500486015

Lafrenière, M., Bélanger, J., Sedikides, C., \& Vallerand, R. (2011). Self-esteem and passion for activities. Personality and Individual Differences, 51, 541-544.

Lewis, M. (2021). Emails indicate Amazon's use of force while seeking JEDI cloud contract, GOP lawmakers say. GeekWire.

Lucas, J. R. (1999). The Passionate Organization: Igniting the Fire of Employee Commitment. AMACOM.

Luo, Z., Bai, X., Min, R., Tang, C., \& Fang, P. (2014). Factors influencing the work passion of Chinese community health service workers: an investigation in five provinces. BMC Family Practice, 15(1), 77-77. https://doi.org/10.1186/1471-2296-15-77

Mahmoudi, A., Deng, X., Javed, S. A., \& Zhang, N. (2021). Sustainable Supplier Selection in Megaprojects through Grey Ordinal Priority Approach. Business Strategy and The Environment, 30, 318-339. https://doi.org/10.1002/bse.2623

Makino, S., Tse, C. H., Li, S. Y., \& Li, M. Y. (2020). Passion transfer across national borders. Journal of Business Research, 108, 213-231. https://doi.org/10.1016/j.jbusres.2019.11.014

Martin, K. (2021). On the origin of Hume's philosophy in the passions. Journal of Economic Behavior and Organization, 184, 860-873. https://doi.org/10.1016/j.jebo.2020.08.036

McCarter, M. W., Fawcett, S. E., \& Magnan, G. M. (2005). The effect of people on the supply chain world: Some overlooked issues. Human Systems Management, 24(3), 197-208. https://doi.org/10.3233/HSM-2005-24302

Murnieks, C. Y., \& Cardon, M. S. (2019). Fire in the Office: Identities and Passion at Work (pp. 67-104). Passion for Work. https://doi.org/10.1093/oso/9780190648626.003.0003

Murphy, J., \& Smith, S. (2009). Chefs and suppliers: an exploratory look at supply chain issues in an upscale restaurant alliance. International Journal of Hospitality Management, 28(2), 212-220. https://doi.org/10.1016/j.ijhm.2008.07.003

Nature. (2020). IRBM unleashes its passion for science on the global drug discovery market. Nature Reviews Drug Discovery. Retrieved from https://www.nature.com/articles/d42473-020-00068-1

Nawaz, M., Abid, G., Arya, B., Bhatti, G. A., \& Farooqi, S. (2020). Understanding employee thriving: The role of workplace context, personality and individual resources. Total Quality Management \& Business Excellence, 31(11-12), 1345-1362. https://doi.org/10.1080/14783363.2018.1482209 
Nawaz, M., Bhatti, G. A., Ahmad, S., \& Ahmed, Z. (2018). How can the organizational commitment of Pakistan railways' employees be improved? The moderating role of psychological capital. Journal of Entrepreneurship, Management and Innovation, 14(1), 123-142.

Nix, N. (2019). Amazon Sues Over Loss of Pentagon Cloud Deal to Microsoft. Yahoo! Finance.

Perttula, K. H. (2004). The POW factor: Understanding and igniting passion for one's work. Unpublished doctoral dissertation, University of Southern California, Los Angeles, California.

Ratelle, C. F., Vallerand, R. J., Mageau, G. A., Rousseau, F. L., \& Provencher, P. J. (2004). When passion leads to problematic outcomes. Journal of Gambling Studies, 25, 105-119. https://doi.org/10.1023/B:JOGS.0000022304.96042.e6

Regan, B. (2018). Cuba's passion for education is an inspiration to all. Morning Star. Retrieved from https://morningstaronline.co.uk/article/cubas-passion-education-inspiration-all

Ryan, R., \& Deci, E. (2000). Self-determination theory and the facilitation of intrinsic motivation, social development, and well-being. American Psychologist, 55, 68-78.

Shane, S., Locke, E. A., \& Collins, C. J. (2003). Entrepreneurial motivation. Human Resource Management Review, 13(2), 257-279. https://doi.org/10.1016/S1053-4822(03)00017-2

Smilor, R. W. (1997). Entrepreneurship: Reflections on a subversive activity. Journal of Business Venturing, 12(5), 341-346. https://doi.org/10.1016/S0883-9026(97)00008-6

Stalin, J. V. (1954). Briefly About The Disagreements In The Party. Works (Vol. 1; pp.90-132). Moscow: Foreign Languages Publishing House.

Vallerand, R. J., Blanchard, C., Mageau, G. A., Koestner, R., Ratelle, C., Léonard, M., ... \& Marsolais, J. (2003). Les passions de l'ame: on obsessive and harmonious passion. Journal of Personality and Social Psychology, 85(4), 756767. https://doi.org/10.1037/0022-3514.85.4.756

Vallerand, R. J., Paquet, Y., Philippe, F. L., \& Charest, J. (2010). On the role of passion for work in burnout: A process model. Journal of Personality, 78, 289-312. https://doi.org/10.1111/j.1467-6494.2009.00616.x

Wieland, A. (2021). Dancing the supply chain: Toward transformative supply chain management. Journal of Supply Chain Management, 57(1), 58-73. https://doi.org/10.1111/jscm.12248

Zigarmi, D., Houson, D., Diehl, J., \& Witt, D. (2010). Employee work passion: A new look at engagement. Chief Learning Officer, 48, 24-27.

Zigarmi, D., Nimon, K., Houson, D., Witt, D., \& Diehl, J. (2009). Beyond engagement: Toward a framework and operational definition for employee work passion. Human Resource Development Review, 8(3), 300-326. https://doi.org/10.1177/1534484309338171

Zigarmi, D., Nimon, K., Houson, D., Witt, D., \& Diehl, J. (2011). A preliminary field test of an employee work passion model. Human Resource Development Quarterly, 22(2), 195-221. https://doi.org/10.1002/hrdq.20076. 